\title{
Negative views of Islam in Switzerland with special regard to religiosity as an explanatory factor
}

\author{
Alexander Yendell • Stefan Huber
}

Published online: 6 May 2020

(C) The Author(s) 2020

\begin{abstract}
Drawing on such theoretical paradigms as Social Identity Theory, the deprivation hypothesis, and the concept of trust, we sought to investigate how religiosity relates to attitudes towards Islam among the Swiss population. In this quantitative study based on the data of the Swiss Household Panel $2015(n=10,848)$ we took into account both public religious practice and personal religiosity. A hierarchical linear regression analysis revealed that religiosity influenced attitudes towards Islam, in that affiliation to one of the large churches (Protestant or Catholic), had a weak positive influence, which might in turn reflect a focus within the large churches on religious freedom and inter-religious dialogue. The effect of church attendance in general on attitudes was positive albeit rather weak. In comparison, personal religiosity was important, with people with a high level of personal religiosity being more likely to have a positive attitude towards Islam. One important finding was that religiosity contributed more to explaining variance than did other factors such as social trust, political position or national identity. Other influential factors included political attitude and trust in other people. The study also revealed that those Swiss people for whom national identity was particularly important were more likely to have a negative view of Islam. While belonging to an Evangelical denomination was significant in our regression models, and exerted an even stronger negative impact when variables of religiosity were included, the impact lost its significance in models which included the importance of Swiss identity. We conclude that Evangelicals are more negative towards Islam not because of their religiosity, but because they tend to have a strong national identity.
\end{abstract}

\footnotetext{
A. Yendell (ه)

Institut für Praktische Theologie, Universität Leipzig, Martin-Luther-Ring 3, Leipzig, Germany

E-Mail: alexander.yendell@uni-leipzig.de

S. Huber

Universität Bern, Institut für Empirische Religionsforschung, Länggassstrasse 51, 3012 Bern,

Switzerland

E-Mail: stefan.huber@theol.unibe.ch
} 
Keywords Islamophobia $\cdot$ Switzerland $\cdot$ Religiosity $\cdot$ Prejudices $\cdot$ Religion

\section{Introduction}

Religiosity in connection with Islamophobia is currently an important issue for two reasons. First, virtually all right-wing populist movements and parties refer in their Islamophobic politics to Christianity as the foundation of their culture. Referring to Christianity_or, better, using the Christian heritage together with antiIslamic rhetoric - has become one of the key features that all populist parties and movements in Europe share (Hidalgo et al. 2019). While spreading false views of multiculturalism, these parties and movements create the impression that there is an uncontrollable flood of Muslims into the Christian-Jewish Occident. From a sociopsychological point of view, right-wing populists, with their Christian worldview and their fear of Islam, contribute to the marking of identity by dividing the world into the good "us" and the evil or dangerous "them". The question that arises is whether this in-group and out-group division also applies to Christian communities (ibid.).

Second, the churches are being increasingly challenged to position themselves within an increasingly diverse religious field. While they might have an interest in tolerance and religious freedom, they are confronted with church members who are prone to right-wing populism and Islamophobia. To support tolerance, they can refer to theological positions within Christianity, such as providing shelter for refugees, and the commandment to love thy neighbour. In Switzerland, both the Protestant and the Catholic Church tend to support Islam and its right to recognition, and to promote interreligious dialogue. ${ }^{1}$

Switzerland is an example of a country where a right-wing populist party, the "Schweizerische Volkspartei" (SVP), has been the strongest party since the parliamentary elections in 1999. It demands a restrictive immigration policy and the combatting of radical Islam, which, according to its critics, also limits the lives of moderate Muslims. For example, it demands that the state not recognize Islam and that it monitor mosques. Switzerland made international headlines in 2009 when, as a result of a popular initiative, minarets were banned, despite the fact that only a few minarets actually existed. Extreme right-wing Swiss parties demanded that the funding of mosques with money from abroad be banned, that sermons be held in the local language, and that the education of imams be controlled (AdemovićOmercic 2018, p. 650). Other demands include restrictions on the import of halal meat, a ban on Islamic religious care, preventing the education of imams at state universities, and withholding legal recognition from Islamic religious communities (ibid.). Given this background, it is not surprising that there are anti-Muslim crimes

\footnotetext{
1 In an Islam project, the Swiss Protestant Federation of Churches set itself a number of goals in 2006, one of which is an active commitment to the religious freedom of Muslims and the creation of ethical guidelines with Islamic faith communities (Schweizerischer Evangelischer Kirchenbund). As the largest church in Switzerland, the Catholic Church sees actively supporting interreligious dialogue as its duty (Christkatholische Kirchgemeinde Luzern; Reformierte Kirche Kanton Luzern und Römisch-katholische Landeskirche des Kantons Luzern/Bischofsvikariat St. Viktor 2014).
} 
in Switzerland, with between 20 and 30 such incidents having occurred in 2017 (ibid.).

For Islamophobic and right-wing populist demands to have a chance of success, they need a breeding ground, and negative attitudes towards Islam are indeed at a high level in Switzerland. In 2013, about half of the Swiss population felt threatened by Islam (Pickel and Yendell 2016, p. 291). A recent poll by the Federal Statistical Office (2019) reveals that $29 \%$ of the Swiss population are sceptical towards Islam, and $11 \%$ are even hostile towards Muslims (BFS 2019, p. 10). A poll conducted in 2016 by the Sonntagszeitung and La matine Dimanche revealed that only $39 \%$ of the Swiss population agree with giving legal recognition to Islam (Tagesanzeiger, 6 November 2016). The same poll shows that only $38 \%$ believe that Islam has a place in Switzerland, and that $80 \%$ believe that the Swiss identity is shaped entirely by Christianity.

These final two figures might lead us to believe that there is a connection between the rejection of Islam on the one hand, and the belief among Swiss people that they are strongly influenced by Christianity on the other. After all, little is known about why the Swiss feel threatened by, and largely oppose, Islam. Research on Islamophobia, specifically in Switzerland, is still in its infancy. However, there is broad international research on xenophobia and on Islamophobia in particular (e.g. Yendell and Pickel 2019; Liedhegener et al. 2019; Bayarakli and Hafez 2018; Kaya 2015; Ogan et al. 2013; Pollack et al. 2014). Studies that analyze the data collected through opinion surveys often reveal that people are more likely to have Islamophobic views if they are economically deprived, feel threatened, have an authoritarian mindset, and harbour strong nationalist and extreme right-wing views and/or have hardly any positive, direct contact with Muslims. At the same time, the role that religiosity plays regarding Islamophobic views and anti-Muslim sentiments has been largely unexplored in quantitative research. This is partly because quantitative research on prejudice often places no importance on the influence of religiosity, and because studies do not take into account religious indicators. Furthermore, quantitative research on religion rarely deals with prejudices and xenophobia. There is, then, a significant research deficit. This paper is primarily concerned with finding out what role religion or religiosity, in interaction with other factors, plays in explaining attitudes towards Islam.

\section{Religiosity as a factor to explain Islamophobia and anti-Muslim sentiments}

One of the most common definitions of Islamophobia is provided by the Runnymede Trust (1997), which defines Islamophobia as "unfounded hostility towards Muslims, and therefore fear or dislike of all or most Muslims". Berger and Berger define Islamophobia as "prejudiced and discriminating behaviour that is directed against people that are perceived as having a Muslim background" (Berger and Berger 2019 , p. 86). Both definitions foreground xenophobia in relation to a particular group of people, but omit the fear that people have of a religion and the doctrine or ideology that they associate with the religion. Other definitions include Islam as 
a religion. A simple definition is provided by Erik Bleich, who defines Islamophobia as "indiscriminate negative attitudes or emotions directed at Islam or Muslims" (Bleich 2012, p. 182). Stolz (2005, p. 548), meanwhile, defines Islamophobia as "a rejection of Islam, Muslim groups, Muslim individuals on the basis of prejudices and stereotypes. It may have emotional, cognitive, evaluative as well as actionoriented elements (e.g. discrimination, violence)".

While the English-speaking world mainly uses the term "Islamophobia", the German-speaking world also uses other terms to denote the devaluation of Islam and anti-Muslim racism (e.g. Islamfeindlichkeit, Muslimfeindlichkeit, Islamhass). Critics of the term "Islamophobia" often argue that negative attitudes towards Islam have more to do with scepticism towards Islam or criticism of Islam. However, Farid Hafez $(2019$, p. 24) criticizes this objection, pointing out that there is no broader concept in public debates such as "criticism of Christianity" or "criticism of Judaism", and that there is also no extensive criticism of the term "homophobia". He already sees in it a special treatment of Islam that justifies the term "Islamophobia".

For our analysis, it is not crucial to define the term, because the primary question is whether attitudes towards Islam, especially in a complex multivariate model, can be explained by indicators of religiosity and indicators derived from prominent theories that explain prejudices. In summarizing the state of research, we join the discussion in the Anglo-Saxon world, which has largely adopted the term "Islamophobia".

\subsection{Research on Islamophobia and anti-Muslim sentiments}

Among the few recent studies that focus on religious indicators related to Islamophobia or anti-Muslim sentiments is the study "Perception and Acceptance of Religious Diversity", which was conducted by the Cluster of Excellence "Religion and Politics" at the University of Münster (Pollack et al. 2014). Based on those data, a multivariate model analyzing attitudes towards Muslims in Germany, Denmark, France, the Netherlands and Portugal reveals that religious exclusivism, i.e. the belief that it is only one's own religion that contains truth, has a negative impact on attitudes towards Muslims (see Pollack 2014, p. 52). In addition, it also reveals that a pluralistic religious orientation has a positive effect on such attitudes in Germany and the Netherlands, which means that those drawing on the teachings of different religions are very likely to have a positive attitude towards Muslims. However, the effect is weak. Furthermore, whether a person belongs to a particular denomination is also significant, albeit only weakly, and it is only statistically significant for West Germany and the Netherlands. Those who belong to a particular denomination tend to be slightly more positive towards Muslims than those who do not. Drawing on the same data, Yendell established that, besides religious exclusivism, which has a negative effect on attitudes towards Muslims, religious pluralism and the frequency of attending church service is positively correlated with tolerance towards Muslims (see Yendell 2014, p. 72). In conclusion, these analyses show that the relationship between religion and Islamophobia has no clear direction. On the one hand, it seems that xenophobia is fostered by religious exclusivism; on the other, that religious pluralism and church attendance prevent xenophobia. However, it is also important to bear in mind that, combined with other indicators, the few religious indicators that 
exist are not as relevant as, for example, the number of contacts that a person has with Muslims. Contact proves to be the most important indicator in the study, as it reduces prejudice.

Drawing on data from the German General Social Survey (ALLBUS 2012), Rebenstorf (2018) has found that endorsement of the item "no religion contains truths" correlates with Islamophobia, which suggests that atheism is positively correlated with Islamophobia. In addition, people are more likely to reject Islam if they attach importance to believing in God and have an exclusivist claim to religion, while church attendance tends to decrease rejection of Islam.

Drawing on the Leipzig Authoritarianism Study 2018, Pickel and Yendell point out that Protestants and Catholics are more open to authoritarian attitudes than nonChristians (Pickel and Yendell 2018, p. 221-223). However, there is no significant difference between the three groups in terms of anti-Muslim sentiments (Pickel and Yendell 2018, p. 221-223).

Using data from the Portraits of American Life Study 2006, Jung (2012) has shown that Christians are more likely to have a low level of respect for Islam. The image of a God who punishes his followers correlates positively with disrespect for Islam. Jung's study also considered the out-group contacts of religious groups, and found that, while a higher frequency of contact with Muslims coincides with a higher tendency to respect Islam, this does not apply to evangelical and black Protestants. In other words, increased contact with Muslims leads to a lower level of respect for Islam among these two groups, which might be due to their high levels of exclusivity (Jung 2012, p. 123).

A paper by Stephanie Doebler (2014) has discussed the correlations between religiosity and intolerance towards Muslims among Europeans towards immigrants living in countries that are predominantly non-Muslim. By analyzing data from the fourth wave of the European Values Study (2010), Doebler establishes that religiosity does indeed matter when it comes to people's attitudes towards Muslims. She concludes that traditional, as well as modern, beliefs in a higher being are strongly and negatively correlated with intolerance towards Muslims, and that fundamentalism is positively correlated with the derogation of Muslims.

In America and the Challenges of Religious Diversity, the American sociologist of religion Robert Wuthnow (2005) identifies three groups on the basis of their religiosity and their attitudes towards Islam. First, the "Spiritual Shopper", who has come into contact with various religious traditions through, for example, education and travel. The Spiritual Shopper integrates other religious traditions into her own faith in the sense of a syncretistic religious orientation. Second, the "Christian Inclusivist", who practices her Christian faith but is not religiously dogmatic. The Inclusivist also critically reflects on her own religious worldview in the sense of a quest religiosity. Third, the "Christian Exclusivist", who is religiously dogmatic and believes that only her own religion is true. Exclusivists are often people who have grown up in authoritarian families, were subjected to strict religious rules, and have rigid learning habits. While "only" $37 \%$ of Spiritual Shoppers find Islam fanatical, that figure is $47 \%$ for Christian Inclusivists and 55\% for Christian Exclusivists (ibid.: 216). Spiritual Shoppers have more contact with Muslims than Christian Inclusivists and Christian Exclusivists (32\% vs. $22 \%$ vs. 19\%). Moreover, Spiritual 
Shoppers are more likely than the other two groups to say that they are very, or at least somewhat, familiar with the basic teachings of Islam (Spiritual Shoppers, 50\%; Christian Inclusivists, 28\%; Christian Exclusivists, 34\%) (ibid.: 206). Spiritual Shoppers also have more contact with Muslims than Inclusivists and Exclusivists ( $32 \%$ vs. $22 \%$ vs. $19 \%$ ). $71 \%$ of Spiritual Shoppers support the idea of Muslims becoming a stronger presence, whereas that figure is only $50 \%$ for Inclusivists and $36 \%$ for Exclusivists. $46 \%$ of Exclusivists even agree that it should be more difficult for Muslims to settle in the US (Inclusivists, 42\%; Spiritual Shoppers, 24\%) (ibid.: 217).

Pollack and Yendell have also discussed Islamophobia according to typologies (Pollack and Yendell 2010). Using a cluster analysis of data from a population survey in Münster. They differentiate between three milieus: the goodwill-tolerants, who are mostly tolerant of all religions, who do not regard immigration by Muslims as a problem, and who support the buildings of mosques; the critically-tolerant, who mostly perceive Muslims as a cause of conflict, but at the same time approve the building of mosques; and the threatened, who mostly believe that Muslims cause societal conflicts, and who are unlikely to support the building of mosques (ibid.). They also state that there is no connection between denomination and tolerance, arguing instead that tolerance is related to the German middle class, a person's level of education, and green-alternative political and post-materialist attitudes (ibid.).

\subsection{Religiosity and research on prejudice other than Islamophobia}

As the previous section showed, studies on the connection between religiosity and Islamophobia are problematical. On the one hand, not many studies have considered religiosity as a relevant variable; on the other, variables of religiosity produce results that are either undifferentiated (for example, because only denomination was taken into account) or contradictory.

What about the results produced by other studies in prejudice research that take religiosity into account? One of the most prominent studies on the relationship between religiosity and prejudices was conducted by Gordon Allport and Michael Ross (1967), who examined the relationship between prejudice and religious motivation by differentiating between intrinsic and extrinsic religiosity. They define the former as an end in itself, and the latter as the means to achieve a self-serving end. For them, people with an intrinsic religiosity are less prejudiced along ethnic lines than people with an extrinsic religiosity (Allport and Ross 1967, p. 441). They concluded that it is especially those who embody intrinsic and extrinsic motivation ("indiscriminately pro-religious people") who are particularly intolerant because they have a "dogmatic mind", which leads them to adopting undifferentiated perceptions (see Allport and Ross 1967, p. 441). They argue:

It seems probable that people with undifferentiated styles of thinking (and feeling) are not entirely secure in a world that for the most part demands fine and accurate distinctions. The resulting diffuse anxiety may well dispose them to grapple onto religion and to distrust strange ethnic groups. 
The difference between intrinsic and extrinsic religiosity also played a role in a survey conducted on racial prejudices by Batson et al. (1978), who also introduced quest religiosity as a third category. They found that controlling for the effects of social desirability cause the negative correlation between intrinsic religion and prejudice either to diminish or disappear. However, even when social desirability was controlled, quest religion correlated negatively with racial prejudice.

Scheepers et al. (2002) examined the relationship between different dimensions of religiosity and prejudice in eleven cross-national European samples. Their analysis reveals that Catholics and Protestants are more prejudiced against ethnic minorities than non-religious people. They also found that frequency of church attendance is positively correlated with prejudices; that subscribing to doctrinal beliefs reduces prejudice; and that the salience of religiosity and spirituality is negatively correlated with prejudice, whereas religious particularism is positively correlated.

Doktór emphasizes the importance of authoritarianism, dogmatism and fundamentalism, which in his study are the strongest predictors of rejection of new religious movements (Doktór 2002, p. 558-559). Jelen and Wilcox (1991) find that dogmatism and belonging to a Protestant denomination affect political intolerance. In a recent study, Merino also notes that a religiously-exclusive position reduces a person's willingness to grant the same rights to members of non-Christian religious communities in American society (see Merino 2010, p. 243). In a study on the influence of religious beliefs on the acceptance of homosexuality, Herek finds that the intrinsically oriented are even more intolerant than the extrinsically oriented. In his opinion, an intrinsic religious orientation only increases tolerance for other groups if the religious doctrine that a person follows calls for tolerance towards the corresponding group (see Herek 1987, p. 35). Herek also believes that religious fundamentalism can better explain prejudices against particular groups than extrinsic or intrinsic religiosity (Herek 1987, p. 40).

Drawing on the Leipzig Study on Authoritarianism, Pickel and Yendell (2018) find no significant differences between Catholics, Protestants and those without a denomination regarding right-wing extremist attitudes as well as anti-Muslim sentiments, antiziganism, xenophobia and anti-Semitism (Pickel and Yendell 2018, p. 221-223). Previous waves of the same $\operatorname{study}^{2}$ do not show a consistent picture (see also Rebenstorf 2018). In the 2010 wave (Decker et al. 2010), it is the Protestants who have the highest values for different dimensions of right-wing extremism; in the 2012 wave, those without a denomination (Decker et al. 2012); and, in the 2014 and 2016 waves (Decker et al. 2014, 2016), Catholics. In a study based on the data "Deutsche Zustände", Küpper and Zick reveal that it is Protestants who are most likely to have racist views, and those without a denomination who are least likely (Küpper and Zick 2006). Other studies by the same authors show either only small effects or effects regarding only a few minorities (for instance, not Muslims) (Zick and Küpper 2014). In a comparative country study, they conclude that there actually is a correlation between religiosity and prejudice: the more religious people are, the more likely they are to be prejudiced. But they also conclude that the effect

\footnotetext{
${ }^{2}$ In the waves before the Leipzig Study on Authoritarianism was named the Centre Study at Leipzig University (Mitte-Studie an der Universität Leipzig).
} 
of religiosity is very weak, and that not every form of religiosity is problematical (Küpper and Zick 2010, 2016).

Ekici and Yucel (2014) analyzed data from the European Values Study (EVS) 2008 , and discussed the effects of religiosity on religious and racial prejudice in Europe. Religious prejudice was measured according to the question of which neighbours people would not like to have (Christian, Muslims, Jews), and subsumed under one variable. They reveal that religious particularism coincides with more religious and racial prejudice, whereas doctrinal belief and individual spirituality are both correlated with less religious prejudice. They also found that nonreligious individuals have a higher level of religious prejudice than members of religious denominations.

In a study on extreme right-wing attitudes, Huber and Yendell (2019) analyzed data from the German General Social Survey (ALLBUS 2018), and differentiated between commitment to the church, attachment to God, and belief in supernatural powers. Their findings reveal that commitment to the church is negatively correlated, and belief in supernatural powers is positively correlated, with right-wing extremist views, whereas attachment to God plays no significant role.

The results of the very few studies which consider religiosity to be an indicator of prejudices, racism and Islamophobia give the impression that, if taken into account at all, then religious indicators often play a minor role or produce contradictory results. This is not necessarily due to the fact that religiosity has no explanatory potential; it is also perhaps because previous studies did not sufficiently consider certain forms of religiosity. In this context, religiosity is a black box that needs further examination, not only because the way that previous studies operationalized religiosity produced paradoxical results, but also in order to produce a multidimensional model with the highest possible explained variance.

\section{Theoretical approach}

\subsection{Religiosity}

Because previous surveys on the relationship between religion and prejudice have so far produced no reliable results, Rebenstorf suggests a model of religiosity that goes beyond the usual characteristics of denomination, church attendance, self-assessment of religiosity, and attachment to one's own religious community (Rebenstorf 2018, p. 319), and points to the model developed by Huber and Huber (2012) as an example. This model divides religiosity into psychological and sociological core dimensions (Huber and Huber 2012; Huber 2003; Huber and Krech 2009):

- Intellect, which consists of themes of interest, hermeneutical skills, styles of thought and interpretation, and bodies of knowledge. A general indicator is the frequency with which a person thinks about religious issues.

- Ideology, which in the personal religious construct system is represented as beliefs, unquestioned convictions, and patterns of plausibility. A general indicator is belief in the existence of a transcendent reality. 
- Public practice, which refers to the fact that religious individuals belong to religious communities, and that this expresses itself in public participation in religious rituals and communal activities (e.g. church attendance for Christians, and "Friday prayer" for Muslims).

- Private practice, which means that religious people devote themselves to transcendence in the private space. General indicators are prayer and meditation.

- Experience, which refers to patterns of religious perceptions and the body of religious experiences and feelings that have an emotional connotation (e.g. experiencing transcendence as "one-to-one experiences", which correspond to a dialogical pattern of spirituality, and "experiences of being at one", which correspond to a participative pattern of spirituality).

There are two ideas in the model that promise to be particularly fruitful in explaining people's attitudes towards other religions: the idea of religious orientation postulated by Allport and Ross (1967), and the idea of identification with a social in-group as discussed in Social Identity Theory (Tajfel and Turner 1986), which in the case of religiosity is identification with a religiously labelled group.

First, an index can be derived from the dimensions of private practice, experience, ideology, and intellect. This index of personal religiosity has much in common with Allport's intrinsic religious type. Personal religiosity could have a significant impact, in that the more present the experience of transcendence is to something divine or to a higher power, the more likely it is to develop a universalizing dynamic. This could happen if the strength of personal religiosity is accompanied by the internalization of values of humanity such as goodness and love for one's neighbour, which in turn can promote tolerance and openness. That may mitigate the dynamics that we know from social-psychological intergroup theories. This means that we can expect attitudes towards a foreign religion to be positively correlated with personal religiosity.

Second, the kind and strength of social religious identity, which is derived from the dimension public practice, should also play a relevant role. If the relevance of the social relationship for the individual increases, then the dynamics postulated by Social Identity Theory should become stronger. High levels of social religious identity should go along with a stronger identification with the religious in-group, which has implications for the person's relationship with and attitudes towards the religious out-group. Here, however, several scenarios are imaginable. On the one hand, a strong identification with the religious in-group might be accompanied by a devaluation of the religious out-group, especially if the social religious in-group promotes exclusivity. On the other, the values of the religious in-group might also include a degree of openness, and perhaps even a willingness to help other religious communities, which is accompanied by a higher level of tolerance.

The idea of an in-group identity that might play a role in promoting or curbing prejudices comes from Social Identity Theory (SIT) (Tajfel 1982), which argues that an individual's behaviour is determined by her belonging to a group (in-group), which defines itself in relation to other groups (out-group) (see Tajfel and Turner 1986). According to SIT, prejudices are the result of processes of identification with social groups, these processes comprising a person's knowledge that she belongs to 
a social group, and the associated emotional (affective) meaning of that affiliation. In the case of low group membership mobility (social mobility), emotional significance increases and group affiliation attains significance for one's own self-concept (Tajfel and Turner 1986, p. 11, 16). The central driving force is the individual's need for more self-esteem, which can be increased through the (subjectively) high value of the group with which the individual identifies. Therefore, under certain circumstances, people tend to improve their own self-esteem by enhancing the status of their own group and devaluing other groups. One marker of identification with the in-group, and thus of the social demarcation of the out-group, is the extent to which the individual believes that she has to be reliable and loyal to the group. The more loyal a person believes that she has to be, the more likely she is to develop a negative attitude towards an out-group. Under certain circumstances, a dynamic can develop that leads to the construction of further group-related prejudices. Strong identification with the in-group may, for example, be expressed by national pride. In this context, the obvious religious labelling that has occurred since 9/11 could also be problematical, with immigrants from Turkey and Arab countries being more often defined as Muslim, whereas their religious background did not play such an important role before 9/11. In other words, an out-group first has to be defined before it can be derogated. Usually, national pride, which is based on ideas of ethnic rather than civic identity, is assumed to promote prejudices (Yendell 2016; Yendell 2014b; Hjerm 1998; Weins 2004).

Another relevant theory often used in research on prejudices and on right-wing extremism is the deprivation hypothesis (Rippl and Baier 2005; Decker et al. 2010, 2016), which postulates that, when faced with competition for scarce economic resources, economically deprived groups are more likely to derogate immigrants or those perceived as "foreign" (McCutcheon 2000; Rippl and Baier 2005; Decker et al. 2010, 2016). Deprivation theories often distinguish between objective (Dietz 1997, p. 99) and relative deprivation (Stouffer et al. 1949a, 1949b). Objective deprivation is an individual's actual social disadvantage, which can be measured through socioeconomic indicators such as income, employment/unemployment, and social class. Relative deprivation is an individual's subjective assessment of being socially disadvantaged. Rippl and Baier (2005, p. 645) make another important distinction here: namely, between individual deprivation (i.e. the feeling of personal deprivation) and collective deprivation (i.e. the feeling of discrimination with regard to the group, nation or culture to which one belongs). Collective deprivation is usually expected to have a particularly strong influence on the formation of xenophobic attitudes. Many research results confirm the deprivation thesis regarding xenophobia and right-wing extremism (see Becker 2007; Edinger and Hallermann 2001; Winkler 2003). Yendell has found that, while negative attitudes towards Muslims in Germany cannot be explained by indicators of objective deprivation such as unemployment or low income (see Yendell 2014, p. 72ff.), relative deprivation does have a negative (albeit comparatively minor) influence on attitudes toward Muslims (ibid.) Pickel and Öztürk have found that collective deprivation has a small effect with regard to Islamophobia (Pickel and Öztürk 2018, p. 181), which is true for most countries analyzed, with the exception of Austria. 
Another relevant factor that is discussed regarding xenophobia and Islamophobia is trust. There is no general sociological theory of trust, but some sociological theories address trust as an important prerequisite of social cohesion. Georg Simmel (1989) described trust as a form of attenuated inductive knowledge; for Simmel, trust is located between knowledge and ignorance. According to Niklas Luhmann (2009), trust is an advance payment against the backdrop of a lack of information about a complex, unmanageable item. Trust reduces complexity and enables a decision to be made based on intuition. We could therefore assume that, since people are experiencing a more complex world, trust is an even more important resource today than it was in the past. Trust also plays a role in social capital theory, which claims that the core of a functioning community is social capital. For Putnam (2000), this social capital comes from people's willingness to cooperate with each other, with cooperation and mutual support giving rise to trust. An important distinction is between bridging and bonding social capital. While bonding social capital leads to trust within a community, bridging social capital leads to trust between different communities and networks, and is more relevant regarding tolerance towards others. When it comes to religious practice, it is therefore very important, for example, how a religious community or parish defines its relationship to other religions, and whether it engages in dialogue with other religions or not. Thus, distrust might be more applicable to fundamentalist or evangelical Protestants and Christian sects, whereas a high level of trust is more likely to be found in majority religions like Catholicism and Protestantism (see Traunmüller 2011, p. 348).

\section{Methodology and data}

To answer the research question, we analyzed data from the Swiss Household Panel (SHP), which is an annual panel study based on a random sample of private households in Switzerland (see FORS Centre). ${ }^{3}$ All household members are interviewed, mainly by telephone. The SHP focuses on questions concerning living conditions. With a few breaks since the first wave in 1999, the respondents are asked about their confession as well as about how frequently they pray and attend church service. Moreover, the waves from 2012 and 2015 included not only these questions, but also the CRSi-7 (Huber and Huber 2012), which makes possible a more indepth analysis of religiosity. In both waves, there was a question on attitudes towards religions: "What is your personal attitude towards the following religions and worldviews, if 0 means 'very negative' and 10, 'very positive'?” In our analysis of the SHP 2015, we only consider respondents with Swiss nationality who are not Muslim $(n=10,848)$.

\footnotetext{
3 The survey covers a broad range of topics, with the focus being mainly on living conditions. The data collection started in 1999 with a sample of 5074 households containing 12,931 household members. In 2004, a second sample of 2538 households with a total of 6569 household members was added; and, since 2013, the SHP has contained a third sample of 4093 households with 9945 individuals.
} 


\section{Descriptive results}

Fig. 1 shows that, compared with other religions or worldviews, negative attitudes towards Islam are particularly common among the Swiss population: $37 \%$ of the respondents have a rather negative view of Islam, whereas only $13 \%$ have a negative view of Christianity, $15 \%$ of Buddhism, $20 \%$ of Hinduism, $27 \%$ of Judaism, and $31 \%$ of atheism.

Thus, Islam is most often viewed negatively, while Christianity is (perhaps not surprisingly) most often viewed positively. What reasons are there for the negative views of Islam among the Swiss population?

Table 1 consists of indicators that, according to our theoretical approach, might have an influence on attitudes towards Islam. We can expect some of the socio-demographic indicators to be connected to attitudes. For example, it is usually the elderly who have more negative views of Islam than younger people, and the same applies to less educated people, while men are usually more prejudiced than women. Factors of deprivation are the indicator unemployment, personal net income, and a person's estimation of her own financial situation ("We would now like to talk about your financial situation. Overall, how satisfied are you with your financial situation, if 0 means 'not at all satisfied' and 10, 'completely satisfied'?"). Interpersonal trust, meanwhile, is measured by the question, "Would you say that most people can be trusted or that you can't be too careful in dealing with people?, if 0 means 'Can't be too careful' and 10, 'Most people can be trusted'?". A person's political orientation was measured with the question, "When they talk about politics, people mention left and right. Personally, where do you position yourself, if 0 means 'left' and 10, 'right'?". The confessional groups are Protestant (Protestant or Reformed Church), Catholic (Roman Catholic and Christian Catholic), Evangelical, other Christian religions (Orthodox and other Christian denominations), other non-Christian religions

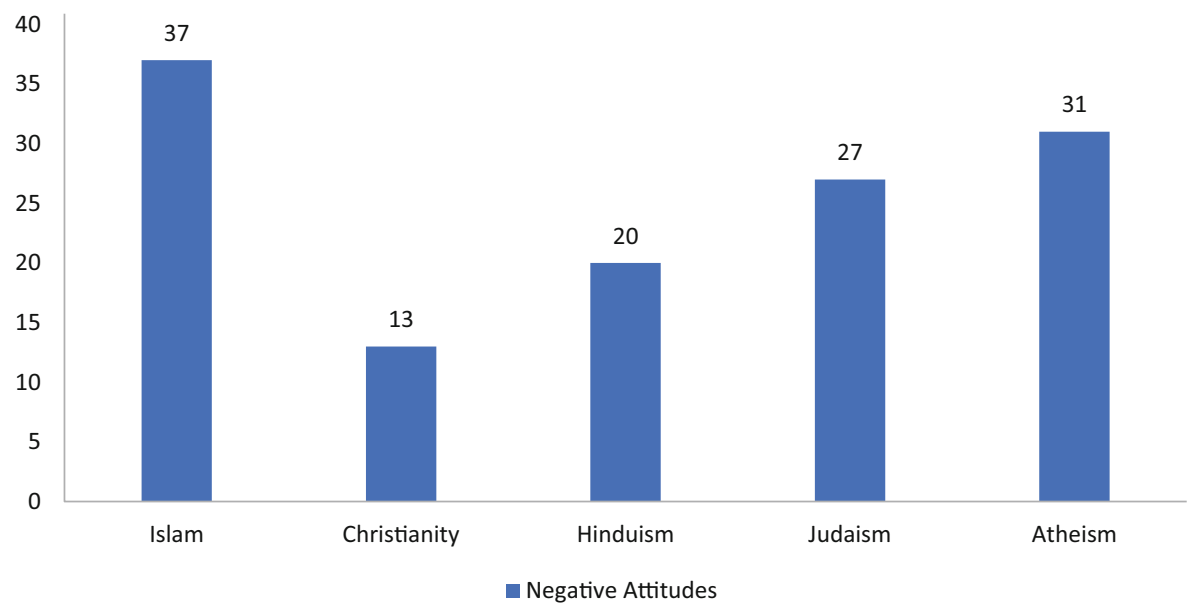

Fig. 1 Negative attitudes towards Islam, other religions, and atheism (in \%). Source: SHP 2015, values weighted, own calculations: question asked: "What is your personal attitude towards the following religions and worldviews, if 0 means 'very negative' and 10, 'very positive'?"; here: negative $=0$ to 4 on the scale 
Table 1 Positive attitudes towards Islam and possible factors of explanation

\begin{tabular}{|c|c|c|c|c|}
\hline Construct & Indicator & Category & Mean & Negative attitudes (\%) \\
\hline \multirow{9}{*}{$\begin{array}{l}\text { Social de- } \\
\text { mography }\end{array}$} & \multirow[t]{5}{*}{$\operatorname{Age}(* * *)$} & Under 20 & 4.9 & 34.1 \\
\hline & & 20 to under 35 & 4.2 & 46.5 \\
\hline & & 35 to under 50 & 4.0 & 48.8 \\
\hline & & 50 to under 65 & 3.9 & 50.6 \\
\hline & & $65+$ & 3.8 & 52.8 \\
\hline & \multirow[t]{2}{*}{$\operatorname{Sex}(* * *)$} & Female & 4.1 & 46.3 \\
\hline & & Male & 3.9 & 51.3 \\
\hline & \multirow[t]{2}{*}{ Education $(* * *)$} & Up to 12 years & 3.8 & 52.1 \\
\hline & & More than 12 years & 4.3 & 44.5 \\
\hline \multirow[t]{9}{*}{ Deprivation } & \multirow{2}{*}{$\begin{array}{l}\text { Unemployment } \\
\text { (n.s.) }\end{array}$} & Unemployed & 4.2 & 43.3 \\
\hline & & Not unemployed & 4.0 & 48.7 \\
\hline & \multirow{3}{*}{$\begin{array}{l}\text { Satisfaction with } \\
\text { financial situation } \\
(* * *)^{\mathrm{a}}\end{array}$} & Not satisfied & 3.4 & 58.6 \\
\hline & & Medium level of satisfaction & 3.8 & 51.4 \\
\hline & & Satisfied & 4.12 & 47.3 \\
\hline & \multirow[t]{4}{*}{ Net income $(* *)$} & Under 30,000 & 4.1 & 46.3 \\
\hline & & 30,000 to under 60,000 & 3.9 & 50.1 \\
\hline & & 60,000 to under 80,000 & 3.9 & 49.5 \\
\hline & & $80,000+$ & 4.1 & 49.0 \\
\hline \multirow[t]{3}{*}{ Trust } & \multirow[t]{3}{*}{ Trust in people***a } & Low trust & 3.03 & 63.6 \\
\hline & & Medium trust & 3.74 & 54.3 \\
\hline & & High trust & 4.42 & 42.2 \\
\hline \multirow{3}{*}{$\begin{array}{l}\text { Political } \\
\text { orienta- } \\
\text { tion }\end{array}$} & \multirow{3}{*}{$\begin{array}{l}\text { Political orientation } \\
* * * \mathrm{a}\end{array}$} & Left & 4.7 & 35.1 \\
\hline & & Middle & 4.2 & 46.5 \\
\hline & & Right & 3.2 & 64.5 \\
\hline \multirow{6}{*}{$\begin{array}{l}\text { Religious } \\
\text { affiliation }\end{array}$} & \multirow[t]{6}{*}{ Confession $* * *$} & Protestant & 4.0 & 48.4 \\
\hline & & Catholic & 4.2 & 46.4 \\
\hline & & Other Christian religion & 3.9 & 52.3 \\
\hline & & Other religion & 4.3 & 43.9 \\
\hline & & No religion (nones) & 3.7 & 53.6 \\
\hline & & Evangelical & 3.6 & 57.6 \\
\hline \multirow{5}{*}{$\begin{array}{l}\text { Social } \\
\text { religiosity }\end{array}$} & \multirow{5}{*}{$\begin{array}{l}\text { Attendance at } \\
\text { church service } \\
(* * *)^{\mathrm{a}}\end{array}$} & Never & 3.7 & 51.5 \\
\hline & & Seldom & 3.8 & 52.0 \\
\hline & & Up to a few times a year & 4.2 & 47.2 \\
\hline & & Every month or two weeks & 4.5 & 43.7 \\
\hline & & $\begin{array}{l}\text { Once or several times } \\
\text { a week }\end{array}$ & 4.3 & 43.9 \\
\hline \multirow{3}{*}{$\begin{array}{l}\text { Personal } \\
\text { religiosity }\end{array}$} & \multirow{6}{*}{$\begin{array}{l}\text { (Ideology, } \\
\text { intellectual } \\
\text { experience, private } \\
\text { practice) }(* * *) \\
\text { Being Swiss }(* * *)^{\mathrm{a}}\end{array}$} & Low (1.0-2.0) & 3.4 & 52.8 \\
\hline & & Medium (2.1-3.9) & 4.0 & 47.2 \\
\hline & & High (4.0-5.0) & 4.3 & 47.5 \\
\hline \multirow{3}{*}{$\begin{array}{l}\text { National } \\
\text { identity }\end{array}$} & & Not important & 4.5 & 33.9 \\
\hline & & Neither/nor & 4.5 & 40.1 \\
\hline & & Very important & 3.8 & 54.2 \\
\hline
\end{tabular}

Source: SHP 2015, own calculations

${ }^{\mathrm{a}} p^{* * *}<0.001, p^{* *}<0.01, p^{*}<0.05$ : questions in the appendix 
(Hinduism, Buddhism, Judaism, and other), and no religion. Other items to measure religiosity are public religious practice (i.e. the frequency of attending church service), and indicators of personal religiosity (thinking about religious questions, belief in God or something divine, maximum value of prayer or meditation, and maximum value of experiencing God's intervention or some kind of divine intervention or feeling as one with God). The indicator for Swiss identity is the question, "To what extent are the following things important for your identity, if 0 means "not important at all' and 10, 'very important'?" (here: being Swiss).

Comparing means and analyzing variance (ANOVA) reveal that, apart from unemployment, all indicators have significant differences between the categories. The oldest group of respondents (those over 65) have more negative attitudes towards Islam than the younger age groups. Women are more positive towards Islam than men, and those with fewer than 13 years of education are significantly more negative towards Islam than those with 13 or more years of education. Income does not correlate in a linear way with attitudes towards Islam, at least if a distinction is made between those who earn less than 30,000, 30,000 to less than 60,000, 60,000 to less than 80,000, and 80,000 and more Swiss Francs. On average, respondents in the middle category have slightly more negative views of Islam than those in the lowest and the highest category. Personal net income does not seem to be a good indicator to explain negative attitudes toward Muslims, and a person's estimation of her own financial situation is a better predictor. Those who view their situation negatively ( 0 to 3 on the 10-point Likert scale) are more negative than those who have a medium view of their situation (4 to 6), and those who view their situation positively (7 to 10). Trust is also significant. Those with a low level of trust (0 to 3 ) are significantly more negative towards Islam than those with a medium (4 to 6) and a high (7 to 10) level of interpersonal trust. A little less than two-thirds of those with a low level of trust have rather negative views of Islam, whereas that figure is "only" slightly more than $40 \%$ among those with high levels of trust.

Regarding confession, nones and Evangelicals, as well as members of other Christian religions, view Islam more negatively than Protestants and Catholics, as well as members of other non-Christian religions. Frequency of church attendance, which measures social religiosity, also plays a role, with those attending church more often being more likely to view Islam positively. Personal religiosity is also correlated with a more positive view of Islam.

However, the importance of feeling Swiss is even more relevant: those who give little importance to being Swiss are far less negative towards Islam than those for whom their Swiss identity is very important (34\% vs. 54\%). The Evangelicals are particularly interesting here. Despite their high levels of social and personal religiosity, which would usually have a positive effect on how people view Islam, Evangelicals are in fact more negative towards Islam than Protestants and Catholics. We assume that the intertwining of national identity and belonging to an Evangelical religious community have an impact on views of Islam. Thus, national identity could be a confounding variable, whereas simply belonging to an Evangelical community may not function as an explanatory variable. Given this, a multivariate analysis might be revealing. 


\section{Multivariate analysis}

To explain why Swiss citizens develop negative attitudes towards Islam, we have conducted a hierarchical regression (Table 2). In each step, only statistically significant indicators are considered. The step-by-step approach also makes it possible to discover whether explanatory variables retain their explanatory power when new indicators are added. In addition, it offers the possibility to describe the change in variance by increasing other variables.

The regression analysis reveals to what extent negative attitudes towards Islam are affected by social-structural characteristics such as gender, age and education (step 1), factors of objective deprivation such as unemployment and personal net income, as well as people's subjective estimation of their own financial situation (step 2), general trust in people (step 3), political orientation (step 4), religious denomination (Protestant, Catholic, Evangelical, another Christian denomination, other religion, or no religion) (step 5), public religious practice (step 6), personal religiosity (step 7), and level of identification with being Swiss as a form of national identity (step 8). There occurred no problems of multicollinearity in the models, as variance inflation factor in each model is less than the threshold values.

The first model, which only considers the socio-structural variables, shows that age has a negative effect $(\mathrm{Beta}=0.13 * * *)$. The older the respondents are, the more likely they are to have a negative attitude towards Islam. This effect was expected and has been confirmed by other studies. A very slight effect $($ Beta $=0.06)$ is that of sex: women are a little more likely than men to have more positive views of Islam. Education also plays a significant role here: the more highly educated people are, the more likely they are to be open to Islam. However, these three socio-structural variables can only explain about $3 \%$ of the variance.

The variance increases by only 0.005 if indicators of deprivation are considered. A striking finding here is that neither unemployment nor annual personal income has an effect, whereas how people estimate their own financial situation is statistically relevant: those respondents who are dissatisfied with their own financial situation are more likely to have a negative view of Islam-although, with a Beta of $0.09 * * *$, the effect is rather weak. The fact that the two indicators of unemployment and income are not significant is particularly interesting, since it shows that what is relevant in this context are not objective forms of deprivation, but rather how people subjectively perceive their situation, which does not necessarily depend on their actual economic situation. This result matches results from other studies on Islamophobia (Yendell and Pickel 2019; Pickel and Yendell 2016; Yendell 2014).

The third model includes general trust, which is a comparatively important indicator when it comes to explaining negative attitudes towards Islam. Not surprisingly, people who have high levels of interpersonal trust tend to have more positive views of Islam. When trust is included in the model, then the variance increases by 0.03 . Trust is more relevant as an explanatory variable (Beta $=0.19 * * *)$ than the indicators in the previous models. Compared with the model from step 2, the other indicators lose a little of their strength when trust is included.

Model 4 includes political position. The explained variance increases by 0.031 with a Beta of $0.194 * * *$. Combined with interpersonal trust, this indicator is a com- 


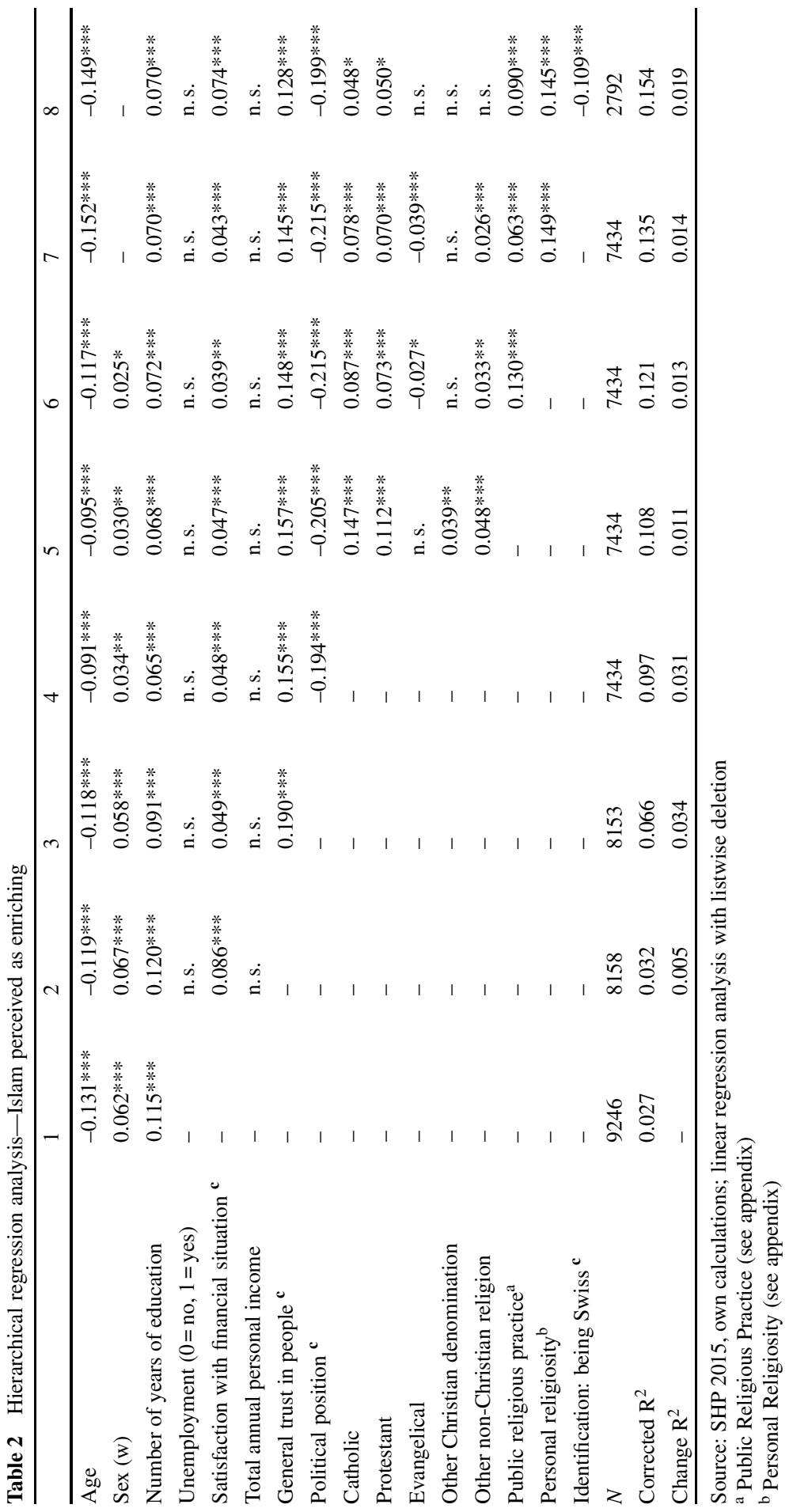


paratively more relevant indicator, which is not surprising since it confirms the current view that the more left-wing people are, the more likely they are to be open towards religious plurality and support the equal treatment of all religious groups.

The indicator of belonging to a religious community is particularly interesting with regard to our central research question. Model 5 includes dummy variables for denominational affiliations. The reference category is "no confession". The variance increases in model 5 by only 0.011 . Belonging to a Catholic religious community has the strongest positive effect on attitudes towards Islam, followed by belonging to a Protestant religious community, while belonging to other Christian or nonChristian denominations plays a very weak role. Surprisingly, whether a person is Evangelical or not does not play a role at all, which could be due to the fact that the reference category is "no religion", and both Evangelicals and people without a religion have relatively negative attitudes towards Islam.

In addition to the other indicators, model 6 adds church attendance as a proxy for public religious practice, which increases the variance by 0.013 . Church attendance plays a significant role (Beta $=0.130 * * *)$, and what is interesting is that the effect of Catholicism and Protestantism diminishes in comparison to the previous model. In model 6, belonging to the Evangelical community plays a significant but weak role $\left(-0.027^{*}\right)$, which was to be expected. Swiss people who are Evangelical are a little more likely to have a negative view of Islam. Interestingly, belonging to the Evangelical community was not significant in the previous model, and only becomes significant when public religious practice is added. This underlines that Evangelicals regard Islam differently to those who belong either to a Catholic or Protestant community, and that Evangelicals are a special group in this respect.

Model 7 adds personal religiosity, and the changes from the previous model are again interesting. The variances increase by 0.014 , and it is noticeable that including the stronger effect of personal religiosity (Beta $=0.149 * * *)$ lowers the effect of church attendance $($ Beta $=0.063)$. The effect of gender is no longer significant in this step. Again, the effects of belonging to a religious community are very interesting: whereas adding personal religiosity weakens the effect in the previous model of belonging to the Catholic $\left(0.078^{* * *}\right)$ or Protestant $\left(0.070^{* * *}\right)$ church, as well as belonging to another non-Christian religious community $\left(0.026^{* * *}\right)$, the effect of belonging to an Evangelical church is stronger than in the previous model, which underlines how different this group is.

The last model adds the level of identification with being Swiss, which again increases the variances, with the R-Square being 0.154. Thus, people's identification with being Swiss is another relevant factor (Beta $\left.=0.109^{* * *}\right)$. Besides people's identification with being Swiss, what also plays a positive (but very weak) role in attitudes towards Islam is belonging to a Catholic or Protestant community. Belonging to a non-Christian religion is no longer significant in the last model. Adding the two indicators of public religious practice and personal religiosity already weakened denomination as a factor, and adding national identity weakens it even further. One relevant result is that belonging to the Evangelical denomination was not significant in the last model. This means that national identity is the more powerful factor, whereas belonging to the Evangelical denomination itself does not necessarily have an impact on views of Islam. What is problematical in this case is national identity: 
Evangelicals are more likely to have negative views if Swiss identity is important to them.

Thus, religious variables lead to an increase in declared variance of $3.8 \%$. In contrast, Swiss identity only leads to an increase of $1.9 \%$, social trust to an increase of $3.4 \%$, and political position to an increase of $3.1 \%$. Therefore, religiosity does indeed play an important role when it comes to explaining Islamophobia.

\section{Conclusion}

We were concerned here with the question of which factors influence attitudes towards Islam. Drawing on such theoretical paradigms as Social Identity Theory, the deprivation hypothesis, and the concept of trust, we sought to investigate how religiosity relates to attitudes towards Islam. Previous research has only been able to provide insufficient answers, since studies on prejudice either pay inadequate attention to questions of religiosity, or use models of religiosity that are not sufficiently differentiated. In contrast, we took into account both public religious practice (as expressed through church attendance) and personal religiosity (operationalized by general measures of private practice, experience, ideology, and intellect). What we found is that religiosity does indeed play a role in that affiliation to one of the large churches (Landeskirchen), i.e. Protestant or Catholic, has a positive effect on attitudes towards Islam, which might be explained by their focus on religious freedom and interreligious dialogue. However, this effect is weak and less important than other factors. The effect of church attendance is also rather weak in that churchgoers are actually slightly less Islamophobic. In comparison, personal religiosity is important, since people with a high level of personal religiosity are more likely to have a positive attitude towards Islam. One important finding is that, of the many factors, religiosity contributes more to explaining variance than, say, social trust, political position and national identity. We therefore suggest that future studies examining the relationship between religiosity and prejudice use a multi-dimensional model such as the CRS (see also Yendell Huber 2020).

Other factors that play a role in explaining views of Islam are political attitude (left-wing people are generally more open to Islam than right-wing people) and trust in other people (those who are more trusting are more positive towards Islam than those who are less trusting). With regard to Social Identity Theory, it is striking that those Swiss people for whom national identity is particularly important are more likely to have a negative view of Islam than those for whom Swiss identity is less important. Thus, both belonging to a religious community and religious practice foster positive attitudes towards Islam, while strong national identification tends to promote exclusivity. This also became obvious in our regression analysis. While belonging to an Evangelical denomination was significant in the regression models, and exerted an even stronger negative impact when variables of religiosity were included, the impact lost its significance when the last model included the importance of Swiss identity. We therefore conclude that religiosity, at least in Switzerland, has a predominantly bridge-building effect, which applies especially to those who belong to the state church and those with high levels of public religious practice 
and personal religiosity. In terms of Social Identity Theory, national awareness leads to a devaluation of religions perceived as foreign, such as Islam. The indicator of national identity is particularly important in its intertwining with religious affiliation. Evangelicals are negative towards Islam not because of their religiosity, but because they tend to have a strong national identity.

One limitation in the analysis is that, due to the limited data available, our model could not include either religious fundamentalism as a likely negative effect, or religious pluralism as a likely positive effect. It would be interesting also to know what role fundamentalist and pluralistic religious orientations play in the formation of prejudice.

Funding We thank Swiss National Science Foundation (SNF) for funding this project (number 100017_1535278).

Funding Open Access funding provided by Projekt DEAL.

Open Access This article is licensed under a Creative Commons Attribution 4.0 International License, which permits use, sharing, adaptation, distribution and reproduction in any medium or format, as long as you give appropriate credit to the original author(s) and the source, provide a link to the Creative Commons licence, and indicate if changes were made. The images or other third party material in this article are included in the article's Creative Commons licence, unless indicated otherwise in a credit line to the material. If material is not included in the article's Creative Commons licence and your intended use is not permitted by statutory regulation or exceeds the permitted use, you will need to obtain permission directly from the copyright holder. To view a copy of this licence, visit http://creativecommons.org/licenses/by/4. $0 \%$

\section{Appendix}

\section{Analyzed questions of the SHP questionnaire 2015}

Deprivation (Satisfaction with financial situation): Overall, how satisfied are you with your financial situation, if 0 means "not at all satisfied" and 10, "completely satisfied"?

Trust in People: Would you say that most people can be trusted or that you can't be too careful in dealing with people, if 0 means "Can't be too careful" and 10, "Most people can be trusted"?

Political orientation: When they talk about politics, people mention left and right. Personally, where do you position yourself, if 0 means "left" and 10, "right"?

Public Religious Practice: How frequently do you take part in religious services? Answers: never, only for family ceremonies, only for religious celebrations, religious celebrations and family events, a few times a year, about once a month, every two weeks, once a week, several times a week.

Personal religiosity: mean for each case, which consists of four indicators:

1. Think of religious questions: How often do you think about religious questions? Answers: never, rarely, occasionally, often, very often

2. belief in God or something divine: To what extent do you believe in God or something divine? Answers: not at all, a little, medium, fairly, very much

3. maximum value in prayer or meditation practice (maximum value of two items): 
3.1) Frequency of prayer: How frequently do you pray apart from at church or within a religious community? Answers: never, a few times a year, about once a month, at least once a week, daily or almost daily, several times a day (the last two categories were recoded into one category)

3.2) Frequency of meditation: How often do you meditate? Answers: never, a few times a year, about once a month, at least once a week, daily or almost daily, several times a day (the last two categories were recoded into one category)

4. maximum value in experiencing God/a divine presence

4.1) Feeling of being at one: How often do you experience situations where you have the feeling that you are at one? Answers: never, rarely, occasionally, often, very often

4.2) Feeling that God intervenes in life: How often do you experience situations where you have the feeling that God or something divine intervenes in your life? Answers: never, rarely, occasionally, often, very often

Identification (being Swiss): To what extent are the following things important for your identity, if 0 means "Not important at all" and 10, "Very important"?

\section{References}

Ademović-Omercic, Nermina. 2018. Islamophobia in Switzerland. National Report 2017. In European Islamophobia Report 2017, ed. Enes Bayrakli, Farid Hafez, 647-670.

Allport, Gordon, and J. Michael Ross. 1967. Personal religious orientation and prejudice. Journal of Personality and Social Psychology 5(4):432-443.

Batson, Daniel, Stephen J. Naifeh, and Suzanne Pate. 1978. Social desirability, religious orientation, and racial prejudice. Journal for the Scientific Study of Religion 17(1):31-41.

Bayraklı, Enes, and Farid Hafez (eds.). 2018. European Islamophobia Report 2017. Istanbul: SETA (Access date: 30 January 2020).

Becker, Birgit. 2007. Ausländerfeindlichkeit in Ost- und Westdeutschland. Theoretische Grundlagen und empirische Analysen. Saarbrücken: VDM Müller.

Berger, Roger, and Joël Berger. 2019. Islamophobia or threat to secularization? Lost letter experiments on the discrimination against muslims in an Urban area of Switzerland. Swiss Journal of Sociology 45(1):83-105. https://doi.org/10.2478/sjs-2019-0005.

Bleich, Erik. 2012. Defining and Researching Islamophobia. Review of Middle East Studies 46(2):180-189. https://doi.org/10.1017/S2151348100003402.

Bundesamt für Statistik. 2019. Erhebung zum Zusammenleben in der Schweiz (ZidS): Ergebnisse 2018. Neuchâtel. https://www.bfs.admin.ch/bfs/de/home/statistiken/bevoelkerung/migration-integration/ zusammenleben-schweiz.assetdetail.7466706.html (Access date: 30 January 2020).

Christkatholische Kirchgemeinde Luzern, and Reformierte Kirche Kanton Luzern und Römisch-katholische Landeskirche des Kantons Luzern / Bischofsvikariat St. Viktor (eds.). 2014. Das Leben teilen. Impule für den interreligiösen Dialog. Luzern: Christkatholische Kirchgemeinde Luzern; Reformierte Kirche Kanton Luzern und Römisch-katholische Landeskirche des Kantons Luzern / Bischofsvikariat St. Viktor.

Decker, Oliver, Johannes Kiess, and Elmar Brähler, eds. 2012. Die Mitte im Umbruch: Rechtsextreme Einstellungen in Deutschland 2012. Bonn: Dietz.

Decker, Oliver, Johannes Kiess, and Elmar Brähler, eds. 2014. Die stabilisierte Mitte: Rechtsextreme Einstellung in Deutschland 2014. Leipzig. http://www.qucosa.de/fileadmin/data/qucosa/documents/ 14490/Mitte_Leipzig_Internet.pdf. Accessed 12 December 2019

Decker, Oliver, Johannes Kiess, Eva Eggers, and Elmar Brähler. 2016. Die „Mitte“-Studie 2016: Methode, Ergebnisse und Langzeitverlauf. In Die enthemmte Mitte. Autoritäre und rechtsextreme Einstellung in Deutschland. Originalausgabe Forschung Psychosozial., ed. Oliver Decker, Johannes Kiess, and Elmar Brähler, 23-66. Gießen: Psychosozial-Verlag. 
Decker, Oliver, Marliese Weißmann, Johannes Kiess, and Elmar Brähler. 2010. Die Mitte in der Krise. Rechtsextreme Einstellungen in Deutschland 2010. Berlin: Friedrich-Ebert-Stiftung Forum Berlin. http://library.fes.de/pdf-files/do/07504.pdf.

Dietz, Berthold. 1997. Soziologie der Armut. Eine Einführung. Frankfurt/Main, New York: Campus.

Doebler, Stephanie. 2014. Relationships between religion and intolerance towards muslims and immigrants in europe: a multilevel analysis. Review of Religious Research 56(1):61-86.

Doktór, Tadeusz. 2002. Factors influencing hostility towards controversial religious groups. Social Compass 49(4):553-562. http://scp.sagepub.com/cgi/reprint/49/4/553.

Edinger, Michael, and Andreas Hallermann. 2001. Rechtsextremismus in Ostdeutschland. Struktur und Ursachen rechtsextremer Einstellungen am Beispiel Thüringens. Zeitschrift für Parlamentsfragen 32(3):588-612.

Ekici, Tufan, and Deniz Yucel. 2015. What determines religious and racial prejudice in europe? The effects of religiosity and trust. Social Indicators Research 122(1):105-133.

Hafez, Farid. 2019. Feindbild Islam. Über die Salonfähigkeit von Rassismus, 1st edn., Wien: Böhlau Wien.

Herek, Gregory M. 1987. Religious orientation and prejudice: a comparison of racial and sexual attitudes. Personality and Social Psychology Bulletin 13(1):34-44.

Hidalgo, Oliver, Philipp W. Hildmann, and Alexander Yendell (eds.). 2019. Religion und Rechtspopulismus.

Hjerm, Mikael. 1998. National identities, national pride and xenophobia: a comparison of four western countries. Acta Sociologica 41(4):335-347.

Huber, S. 2003. Zentralität und Inhalt: Ein neues multidimensionales Messmodell der Religiosität [Centrality and Content: A new multidimensional measurement model of religiosity. Opladen: Leske + Budrich.

Huber, S. 2009. Religion monitor 2008: structuring principles, operational constructs, interpretive strategies. In What the world believes: analysis and commentary on the religion monitor 2008, ed. Bertelsmann Stiftung, 17-51. Gütersloh: Bertelsmann Stiftung.

Huber, S., and O. Huber. 2012. The centrality of religiosity scale (CRS). Religions 3:710-724. https://doi. org/10.3390/rel3030710.

Huber, Stefan, and Volkhard Krech. 2009. The religious field between globalization and Regionalization: comparative perspectives. In What the world believes: analysis and commentary on the religion monitor 2008, ed. Bertelsmann Stiftung, 53-93. Gütersloh: Bertelsmann Stiftung.

Stefan Huber, and Alexander Yendell. 2019. Does religiosity matter?: explaining right-wing extremist attitudes and the vote for the Alternative for Germany (AfD). Religion and society in Central and Eastern Europe 12(1):6-82

Jelen, Ted G., and Clyde Wilcox. 1991. Religious dogmatism among white christians: causes and effects. Review of Religious Research 33(1):32-45.

Jung, Jong Hyun. 2012. Islamophobia? Religion, contact with muslims, and the respect for islam. Review of Religious Research 54(1):113-126.

Kaya, Serdar. 2015. Islamophobia in western Europe: a comparative, multilevel study. Journal of Muslim Minority Affairs 35(3):450-465. https://doi.org/10.1080/13602004.2015.1080952.

Küpper, Beate, and Andreas Zick. 2006. Riskanter Glaube. Religiosität und Abwertung. In Deutsche Zustände. Folge 4, ed. Wilhelm Heitmeyer, 179-188. Frankfurt am Main: Suhrkamp.

Küpper, Beate, and Andreas Zick. 2010. Religion and prejudice in Europe. New empirical findings. London: Alliance Publishing Trust.

Küpper, Beate, and Andreas Zick. 2014. Schützt Religiosität vor Menschenfeindlichkeit oder befördert sie sie? In Was heißt hier Toleranz? Interdisziplinäre Zugänge, ed. Andrea Bieler, Henning Wrogmann, 146-163. Neukirchen-Vluyn: Neukirchener Verlagsgesellschaft.

Küpper, Beate, and Andreas Zick. 2016. Religion und Vorurteile - empirische Zusammenhänge über individuelle Einstellungsmuster. In Handbuch der Religionen, ed. Michael Klöcker, Udo Twuroschka. München: OLZOG.

Liedhegener, Antonius, Gert Pickel, Anastas Odermatt, Alexander Yendell, and Yvonne Jaeckel. Wie Religion ,uns ' trennt - und verbindet: Befunde einer Repräsentativbefragung zur gesellschaftlichen Rolle von religiösen und sozialen Identitäten in Deutschland und der Schweiz 2019. Leipzig University.

Luhmann, Niklas. 2009. Vertrauen. Ein Mechanismus der Reduktion sozialer Komplexität, 4th edn., UTB für Wissenschaft Soziologie fachübergreifend, 2185. Stuttgart: Lucius \& Lucius UTB.

McCutcheon, Allan L. 2000. Religion und Toleranz gegenüber Ausländern. Eine vergleichende Trendanalyse fremdenfeindlicher Gesinnung nach der Vereinigung Deutschlands. In Religiöser und kirchlicher Wandel in Ostdeutschland 1989-1999 Veröffentlichungen der Sektion Religionssoziologie der 
Deutschen Gesellschaft für Soziologie (DGS), 3., ed. Detlef Pollack, Gert Pickel, 87-104. Opladen: Leske + Budrich.

Merino, Stephen M. (2010): Religious diversity in a "Christian nation": The effects of theological exclusivity and interreligious contact on the acceptance of religious diversity. In: Journal for the Scientific Study of Religion 49(2):231-246. https://doi.org/10.1111/j.1468-5906.2010.01506.x.

Ogan, Christine, Lars Willnat, Rosemary Pennington, and Manaf Bashir. 2013. The rise of anti-Muslim prejudice. Media and Islamophobia in Europe and the United States. International Communication Gazette 76(1):27-46. https://doi.org/10.1177/1748048513504048.

Pickel, Gert, and Cemal Öztürk. 2018. Islamophobia without muslims? The "contact hypothesis" as an explanation for anti-muslim attitudes-eastern European societies in a comparative perspective. Journal of Nationalism, Memory \& Language Politics 12(2):162-191. https://doi.org/10.2478/jnmlp-20180009.

Pickel, Gert, and Alexander Yendell. 2016. Islam als Bedrohung? Beschreibung und Erklärung von Einstellungen zum Islam im Ländervergleich. Zeitschrift für Vergleichende Politikwissenschaft 10(3-4):273-309. https://doi.org/10.1007/s12286-016-0309-6.

Pickel, Gert, and Alexander Yendell. 2018. Religion als konfliktärer Faktor im Zusammenhang mit Rechtsextremismus, Muslimfeindschaft und AfD-Wahl. In Flucht ins Autoritäre. Ergebnisse der Leipziger Autoritarismusstudie 2018 (Arbeitstitel), ed. Oliver Decker, Elmar Brähler, 217-242. Gießen: Psychosozial-Verlag.

Pollack, Detlef. 2014. „Das Verhältnis zu den Muslimen.“ In Grenzen der Toleranz: Wahrnehmung und Akzeptanz religiöser Vielfalt in Europa, edited by Detlef Pollack, Olaf Müller, Gergely Rosta, Nils Friedrichs, and Alexander Yendell, 47-57. Veröffentlichungen der Sektion Religionssoziologie der Deutschen Gesellschaft für Soziologie. Wiesbaden: Springer VS.

Pollack, Detlef, and Alexander Yendell. 2010. Religiöse Toleranz in Münster. Ergebnisse einer repräsentativen Umfrage: Exzellenzcluster Religion und Politik der Westfälischen Wilhelms-Universität Münster. http://www.uni-muenster.de/imperia/md/content/religion_und_politik/aktuelles/2010/07_ 2010/ansichtssache_pollack_yendell_2010.pdf.

Pollack, Detlef, Olaf Müller, Gergely Rosta, Nils Friedrichs, and Alexander Yendell (eds.). 2014. Grenzen der Toleranz. Wahrnehmung und Akzeptanz religiöser Vielfalt in Europa. Wiesbaden: Springer VS. Veröffentlichungen der Sektion Religionssoziologie der Deutschen Gesellschaft für Soziologie.

Putnam, Robert D. 2000. Bowling Alone. The Collapse and Revival of American Community. New York, London, Toronto et al.: Simon \& Schuster.

Rebenstorf, Hilke. 2018. „Rechte“ Christen? - Empirische Analysen zur Affinität christlich-religiöser und rechtspopulistischer Positionen. Zeitschrift für Religion, Gesellschaft und Politik 2(2):313-333. https://doi.org/10.1007/s41682-018-0024-z.

Rippl, Susanne, and Dirk Baier. 2005. Das Deprivationskonzept in der Rechtsextremismusforschung. Eine vergleichende Analyse. Kölner Zeitschrift für Soziologie und Sozialpsychologie 57(4):644-666.

Runnymede Trust. 1997. Islamophobia: a challenge for us all. London: Runnymede Trust.

Scheepers, Peer, Mèrove Gijsbert, and Evelyn Hello. 2002. Religiosity and prejudice against ethnic minorities in europe: cross-national tests on a controversial relationship. Review of Religious Research 43(3):242-265.

Schweizerischer Evangelischer Kirchenbund (SEK) (ed.). https://www.evref.ch/themen/interreligioesezusammenarbeit/islam/ (Access date: 28 April 2020)

Simmel, Georg. 1989. Philosophie Des Geldes, 1st edn., Frankfurt am Main: Suhrkamp. Gesamtausgabe 6.

Stolz, J. 2005. Explaining Islamophobia: a test of four theories based on a case of a Swiss city. Swiss Journal of Sociology 31(2):547-566.

Stouffer, Samuel A., Edward A. Suchman, Leland C. DeVinney, Shirley A. Starr, and Robin M. Williams. 1949a. The American Soldier: Adjustment to Army Life. Vol. 1. Princeton, NJ: Princeton University Press.

Stouffer, Samuel A., Arthur A. Lumsdaine, Marion Harper Lumsdaine, Robin M. Williams, Jr., M. Brewster Smith, Irving L. Janis, Shirley Star, and Leonard S. Cottrell Jr. 1949b. The American Soldier: Combat and its Aftermath. Vol. II. Princeton, NJ: Princeton University Press.

Tagesanzeiger (ed.). 2016. Umfrage. Mehrheit der Schweizer lehnt Islam als Religion ab. https://www. tagesanzeiger.ch/leben/gesellschaft/Mehrheit-der-Schweizer-lehnt-Islam-als-Religion-ab/story/ 21132195. Accessed 17 Feb 2019.

Tajfel, Henri. 1982. Gruppenkonflikt und Vorurteil. Entstehung und Funktion sozialer Stereotypen. Bern, Stuttgart, Wien: Huber. http://www.dandelon.com/intelligentSEARCH.nsf/alldocs/ 9362EC0DB5B44D0FC12570C3004FC7E8/. 
Tajfel, Henri, and John C. Turner. 1986. The social identity theory of intergroup behavior. In Psychology of intergroup relations, 2nd edn., ed. Stephen Worchel, William G. Austin, 7-24. Chicago: NelsonHall.

Traunmuller, R. 2011. Moral Communities? Religion as a Source of Social Trust in a Multilevel Analysis of 97 German Regions. European Sociological Review 27(3):346-363

Weins, Cornelia. 2004. Fremdenfeindliche Vorurteile in den Staaten der EU. Wiesbaden: VS. Univ., Diss. - Teilw. zugl.: Trier, 2003.

Winkler, Jürgen R. 2003. Ursachen fremdenfeindlicher Einstellungen in Westeuropa. Befunde einer international vergleichenden Studie. Aus Politik und Zeitgeschichte 26:33-38.

Wuthnow, Robert. 2005. America and the challenges of religious diversity. Princeton, Oxford: Princeton University Press. https://doi.org/10.2307/j.ctt7rmnn.

Yendell, Alexander. 2014. Warum die Bevölkerung Ostdeutschlands gegenüber Muslimen ablehnender eingestellt ist als die Bevölkerung Westdeutschlands. In Grenzen der Toleranz. Wahrnehmung und Akzeptanz religiöser Vielfalt in Europa, ed. Detlef Pollack, Olaf Müller, Gergely Rosta, Nils Friedrichs, and Alexander Yendell, 59-78. Wiesbaden: Springer VS. Veröffentlichungen der Sektion Religionssoziologie der Deutschen Gesellschaft für Soziologie.

Yendell, Alexander. 2014b. Der Zusammenhang zwischen Regelungen der Staatsbürgerschaft, nationaler Identität und der Ablehnung von Muslimen. In Grenzen der Toleranz. Wahrnehmung und Akzeptanz religiöser Vielfalt in Europa, ed. Detlef Pollack, Olaf Müller, Gergely Rosta, Nils Friedrichs, and Alexander Yendell, 111-124. Wiesbaden: Springer VS. Veröffentlichungen der Sektion Religionssoziologie der Deutschen Gesellschaft für Soziologie.

Yendell, Alexander. 2016. In welchem Zusammenhang stehen Regelungen im Bereich der Staatsbürgerschaft und Einstellungen gegenüber Muslimen? In Religionspolitik und Politik der Religionen in Deutschland. Fallstudien und Vergleiche, ed. Antonius Liedhegener, Gert Pickel, 309-325. Wiesbaden: Springer VS. http://link.springer.com/content/pdf/10.1007\%2F978-3-658-11821-1_13.pdf.

Yendell, Alexander, and Stefan Huber. 2020. The relevance of the centrality and content of religiosity for explaining Islamophobia in Switzerland. Religions https://doi.org/10.3390/rel11030129.

Yendell, Alexander, and Gert Pickel. 2019. Islamophobia and anti-Muslim feeling in Saxony-theoretical approaches and empirical findings based on population surveys. Journal of Contemporary European Studies 32(3):1-15. https://doi.org/10.1080/14782804.2019.1680352. 